\title{
Specific Dynamic Action in Premature Infants Kept at and Below the Neutral Temperature
}

\author{
J.MestyáN ${ }^{[27]}$, I.JÁRAI, M. KeKETE and Gy. SoltésZ \\ Department of Pediatrics, University of Pécs, Pécs, Hungary
}

\begin{abstract}
Extract
The calorigenic effect of an artificial formula, Adapta, was examined in premature infants kept at and below the neutral temperature. After a preliminary period of 15-30 minutes, a feeding ( $40-60 \mathrm{ml}$ ) was offered or given by gavage. The test feeding was followed by an experimental period of four hours, during which time oxygen consumption and $\mathrm{CO}_{2}$ production were continuously recorded by an open circuit method using the Kipp diaferometer.

The results of investigations carried out in the zone of thermoneutrality are summarized in table I. The amount of oxygen consumed 30 minutes after ingestion of the formula was already appreciably larger than that corresponding to the basal metabolic rate. At 90 or 120 minutes, the average oxygen consumption was $30 \%$ higher than that at the preliminary level. Oxygen consumption then fell and had approached the fasting level by the end of the period of observation.

In order to obtain the cumulative effect of thermogenesis, total and basal heat production were calculated for a period of four hours. The average amount of total extra calories was $1.7 \mathrm{kcal} / \mathrm{kg}$ which, in relation to basal heat production during the same period of time and to the ingested calories, represented an increase of 26.4 and $9.2 \%$, respectively (table VI).

The changes in oxygen consumption at different levels of thermoregulatory heat production in totally and partially swaddled premature infants maintained at $20-22^{\circ}$ are shown in tables II, III and IV. The responses are also diagrammatically compared (fig.4). It can be seen that the magnitude of specific dynamic action is the same for babies in a thermoneutral and colder environment, despite the difference in the preingestion levels of oxygen consumption. Control experiments in nonfed premature infants revealed that the specific dynamic action of food in a heat-losing environment is not due to muscular activity, but appears in an additive manner and independently of the metabolic increase induced by the cold environment (table V).

The summation of the metabolic response to cold and to food was also reflected by the behavior of body temperature. The ingestion of $50 \mathrm{ml}$ of formula stopped the fall in body temperature and even caused a small transient rise during the period of maximum increase in heat production.
\end{abstract}

\section{Speculation}

When considering the various factors upon which the zone of thermoneutrality depends, it is likely that a protein or calorie-rich feeding may constitute a significant thermal burden to premature infants cared for at neutral temperature. In contrast to thermoneutral conditions, however, the independence of the stimulating effect of food and cold on thermogenesis indicates that specific dynamic action below the critical temperature can be regarded as a useful source of heat to help maintain the body temperature in a heat-losing environment. Future studies are needed to clarify the thermoregulatory significance of postprandial thermogenesis in premature infants cared for under various environmental conditions and maintained on different feeding regimens. 


\section{Introduction}

In studying the energy metabolism of premature infants, data on the contribution of the specific dynamic action (SDA) of food to total energy expended under different environmental conditions were obtained. Although earlier and more recent observations $[1,6,7$, $8,9,12,17,21,22]$ indicate that premature infants respond, to some degree, to the ingestion of food or load of amino acids by an increase in heat production, there is no information available regarding the magnitude and thermoregulatory significance of the calorigenic effect of food in a thermoneutral and a heat-losing environment.

Premature infants are also able to respond to an increase of heat production in a cold environment [2, $3,4,14,18,23]$. The relation between SDA and chemical heat regulation appears to constitute a problem in energy metabolism. RUBNeR [20] found that SDA replaced the metabolic response to cold. It is questionable whether this holds true for premature infants. A recent observation in adults suggests that SDA is independent of changes in an ambient temperature [5]. The present studies were undertaken to explore these relations in premature infants.

\section{Methods}

The metabolic effect of an artificial formula, Adapta [26], was studied in 24 premature infants who were 6 to 28 days of age and weighed between 1300 and $2110 \mathrm{~g}$.

The formula $(70 \mathrm{kcal} / 100 \mathrm{ml})$ containing $3.43 \%$ protein, $1.78 \%$ fat, and $10 \%$ carbohydrate was given by a gastric tube in a volume from 30 to $60 \mathrm{ml}$.

Oxygen consumption and $\mathrm{CO}_{2}$ production were determined by an open circuit method using the Kipp diaferometer. This apparatus measures heat conductivity in a gas [16]. The calibration given by the factory and the reliability of the method were checked frequently and were found to be constant over a long period of time. The recorded values for oxygen consumption, expressed in $\mathrm{ml} / \mathrm{kg} / \mathrm{min}$ (STPD), were performed on the average for $6-10$ minutes at halfhour intervals after feeding. If, during or immediately before these periods, physical activity occurred, the observed average rate of oxygen consumption was omitted. SDA was expressed as the total heat increment during the 4-hour period of observation. In this calculation, for periods of activity in which there was a definite rise in oxygen consumption, interpolation was performed. The caloric value of one liter oxygen was determined from the nonprotein RQ using Michaelis' nomogram [17]. It was assumed that protein metabolism constituted about $15 \%$ of the total metabolism.

$\mathrm{SDA}$, expressed in $\mathrm{kcal} / \mathrm{kg} / 24 \mathrm{~h}$ or $\mathrm{kcal} / \mathrm{kg} / 4 \mathrm{~h}$, was related to the minimal metabolism and the caloric content of the feeding.

The experimental and environmental conditions under which respiratory metabolism was continuously measured were as follows:

Group 1. In the experiments performed within the zone of thermoneutrality, $33-36^{\circ}$, the infant was placed in an incubator under a perspex hood through which room air was drawn at a rate of $4.6 \mathrm{l} / \mathrm{min}$. The lower parts of the trunk and the legs, which were outside the hood, were loosely covered by a nylon sheet attached around the air inlet of the hood, ensuring that the infant expired only into air flowing over the face. Relative humidity ranged between $45-60 \%$. In order to measure the true basal metabolic rate, measurements were started four hours after the last feeding. In premature infants fed on human milk, SDA usually runs its course during a 4-hour fast. The test feeding period was preceded by a control period of 15-30 minutes, during which time great care was taken to measure minimal oxygen consumption. If vigorous movement or restlessness prevented measurement of resting or sleeping metabolism, the experiment was discontinued. When, however, a reliable minimal metabolic rate (i.e., no visible evidence of physical activity) had been obtained, the test feeding was followed by an experimental period of 4 hours, during which time oxygen consumption and $\mathrm{CO}_{2}$ production were continuously recorded. Readings of the diaferometer were made every minute except when reference was made to the room air.

The behavior and physical activity of the infant could be closely followed through the perspex hood. During prolonged and continuous recording of oxygen consumption, transient physical activity of the infant sometimes distorted the metabolic effect of food. In order to distinguish between SDA and the metabolic effect of physical activity, it appeared necessary to assess the intensity of physical activity every minute arbitrarily as follows [16]:

asleep, physically totally quiet;

eyes open or closed with occasional jerks or slight movements;

awake, some activity (moving arms and legs now and then);

intensive and more or less continuous activity;

vigorous activity with crying and restlessness.

Group 2. Four premature infants, swaddled in down feather quilts, were kept at a room temperature of $20-22^{\circ}$. The head, the upper part of the trunk, and the upper limbs were placed under a perspex hood in which air temperature was $1-2^{\circ}$ higher than room 
temperature. Under these environmental conditions, a small metabolic response to cold can be observed [13]. The time course of the experiment before and after the test feeding was essentially the same as it was in the examination performed in the thermoneutral environment.

Groups 3 and 4. In order to obtain a larger metabolic response to an environmental temperature of $20-22^{\circ}$, another series of examinations were carried out on infants with diapers wrapped around the trunk. In addition to measuring oxygen consumption and carbon dioxide production, body temperature was followed by a copper-constantan thermocouple inserted 10-12 $\mathrm{cm}$ into the rectum. These infants were divided into two groups according to the magnitude of the metabolic response to cold.

Before the infants in Groups 2, 3 and 4 were exposed to these environmental conditions, minimal oxygen consumption at the neutral temperature had also been measured.

Group 5. In four partially swaddled and fasting infants who were exposed to an ambient temperature of $20-22^{\circ}$, oxygen consumption was measured for the same period of time as it was in those infants in whom the metabolic effect of the artificial formula was tested.

For statistical analysis, the means and standard errors were calculated. When necessary, significance was estimated by Student's t test.

\section{Results}

\section{The Calorigenic Effect of Food in a Thermoneutral Environment}

Observations were made on eight premature infants who were 6-24 days of age and weighed between 1300 and $2100 \mathrm{~g}$. After a preliminary period of $15-30 \mathrm{~min}-$ utes, a feeding (40-60 ml) was offered or given by gavage. Physical activity of varying intensity and duration is inevitable in the course of an experiment lasting several hours and, in some instances, may make difficult the evaluation of the metabolic effect of food. In the majority of the experiments, however, activity did not appreciably interfere with the exhibition and course of SDA.

In figure 1, two individual experiments are depicted which indicate that oxygen consumption is definitely higher after the feeding than it is during the preliminary period.

In figure 2, two control experiments show a quite different course of oxygen consumption throughout the period of observation. The transient increase in fasting metabolism caused by intermittent physical activity can easily be distinguished from the prolonged rise in resting metabolism following the ingestion of food. Consequently, the elevation seen in figure I can be related to feeding and not to physical activity.

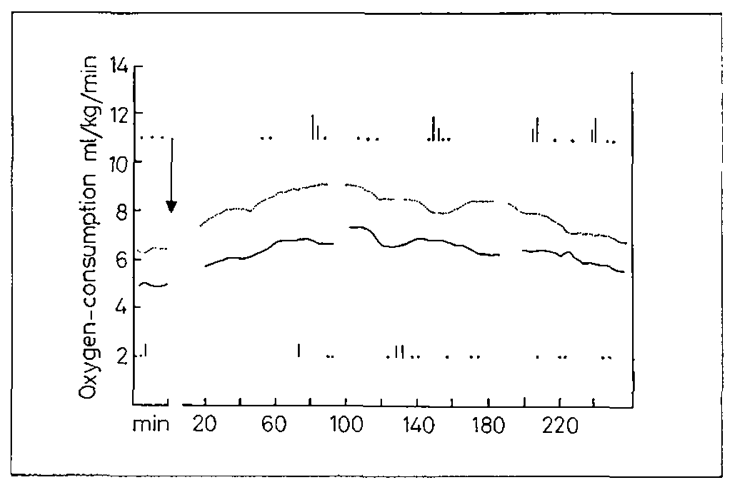

Fig. 1. The oxygen consumption of two premature infants following ingestion of the artificial formula in a thermoneutral environment. Activity is identified as follows:

- $\quad$ eyes closed, occasional jerks;

1 awake, moving arms and legs now and then;

I intensive and more or less continuous activity;

vigorous activity with crying and restlessness.

... 16-day-old premature infant. Body weight: 1610

g. Forty ml of the formula was consumed at the arrow. Activity is indicated above the curves.

6 -day-old premature infant. Body weight: $1400 \mathrm{~g}$. Forty $\mathrm{ml}$ of the formula was given at the arrow. Activity is indicated below the curves.

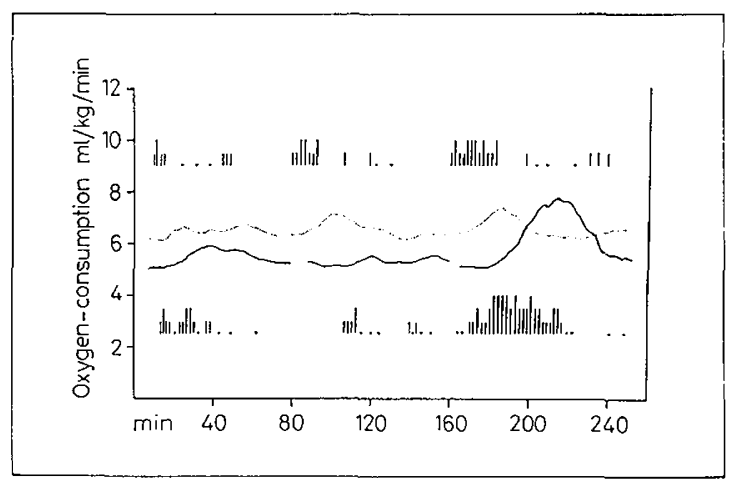

Fig. 2. The oxygen consumption of two fasting premature infants during a period of four hours in a thermoneutral environment. For symbols, see figure 1.

... 10-day-old premature infant. Body weight: 1700 g. Activity indicated above the curves.

—— 5-day-old premature infant. Body weight: $1500 \mathrm{~g}$.

Activity indicated below the curves. 
Table $I$. The oxygen consumption of premature infants kept in a thermal neutral environment after the ingestion of the artificial formula (group 1)

\begin{tabular}{|c|c|c|c|c|c|c|c|c|c|c|c|c|c|}
\hline \multirow[t]{2}{*}{$\begin{array}{l}\text { Age in } \\
\text { days }\end{array}$} & \multirow{2}{*}{$\begin{array}{l}\text { Body } \\
\text { weight } \\
\mathrm{g}\end{array}$} & \multirow{2}{*}{$\begin{array}{l}\text { Ambient } \\
\text { temper- } \\
\text { ature }{ }^{\circ} \mathrm{C}\end{array}$} & \multirow{2}{*}{$\begin{array}{c}\mathrm{O}_{2} \text {-con- } \\
\text { sumption } \\
\mathrm{ml} / \mathrm{kg} / \\
\mathrm{min}\end{array}$} & \multirow{2}{*}{$\begin{array}{c}\text { Quantity } \\
\text { of food } \\
\mathrm{ml}\end{array}$} & \multicolumn{9}{|c|}{$\begin{array}{l}\mathrm{O}_{2} \text {-consumption } \mathrm{ml} / \mathrm{kg} / \mathrm{min} \text { at time (minutes) } \\
\text { after ingestion of food }\end{array}$} \\
\hline & & & & & 30 & 60 & 90 & 120 & 150 & 180 & 210 & 240 & 270 \\
\hline 6 & 1400 & 35.0 & 5.0 & 40 & 6.0 & 6.8 & 6.7 & 6.5 & 6.8 & 6.3 & 6.5 & 6.0 & 5.7 \\
\hline 8 & 1800 & 34.5 & 4.8 & 45 & 5.0 & 5.6 & 7.0 & 6.6 & 6.7 & 5.8 & - & - & - \\
\hline 14 & 1300 & 35.0 & 5.0 & 40 & 5.0 & 4.9 & 5.5 & 5.3 & 5.5 & 5.5 & 5.8 & 5.6 & 5.5 \\
\hline 16 & 1610 & 34.5 & 6.5 & 40 & 8.0 & 8.8 & 9.1 & 8.6 & 8.0 & 8.5 & 8.0 & 7.2 & 6.8 \\
\hline 22 & 1610 & 34.0 & 5.0 & 40 & 7.3 & 6.6 & 7.2 & 7.0 & 6.3 & 6.0 & 6.0 & 5.3 & 5.0 \\
\hline 24 & 1680 & 34.0 & 5.3 & 50 & 7.6 & 7.9 & 7.3 & 6.8 & 6.2 & 6.0 & 6.3 & 6.0 & 5.8 \\
\hline 24 & 2110 & 34.5 & 5.6 & 60 & 6.3 & 6.0 & 5.8 & 6.0 & 5.8 & 5.6 & 5.6 & 5.8 & - \\
\hline 16 & 1650 & 34.0 & 4.2 & 40 & 5.2 & - & 6.0 & - & 4.5 & 5.0 & 4.6 & 4.5 & 4.5 \\
\hline Means & & & 5.2 & 44.5 & 6.3 & 6.6 & 6.8 & 6.7 & 6.2 & 6.1 & 6.1 & 5.8 & 5.5 \\
\hline \multicolumn{3}{|c|}{ Standard error \pm} & 0.24 & & 0.43 & 0.51 & 0.40 & 0.38 & 0.36 & 0.37 & 0.37 & 0.31 & 0.35 \\
\hline
\end{tabular}

The results of investigations carried out in the thermoneutral zone (group 1) are summarized in table I. Oxygen consumption during the preliminary period and at half-hour intervals after feeding are depicted. The rates of metabolism obviously distorted by intensive activity have been omitted. In two instances, the ingestion of formula was not followed by an increase in oxygen consumption; in another infant, physical activity and restlessness obscured the magnitude and duration of the response after 180 minutes.

The average SDA and the time course (group 1) are illustrated in figure 3 . The amount of oxygen consumed 30 minutes after ingestion of the formula was already appreciably larger than that corresponding to the basal metabolic rate. At 90-120 minutes, average oxygen consumption was $6.8 \mathrm{ml} / \mathrm{kg} / \mathrm{min}$, an increase of about 30 percent above the preliminary level. After this time, oxygen consumption fell and approached the fasting level toward the end of the period of observation.

In order to obtain the cumulative thermogenic effect of the formula, total and basal heat production for a period of four hours were calculated. The difference between the two gave the total extra heat produced postprandially above the basal level. The average total extra calories amounted to $1.7 \mathrm{kcal} / \mathrm{kg}$ which, in relation to the total basal heat production during the same period of time and to the ingested calories, represented an increase of 26.4 and $9.2 \%$, respectively (table VI).

The Calorigenic Effect of Food in a Heat-Losing Environment The results obtained in four infants ( 7 to 28 days of age), who were swaddled in down feather quilts and exposed to a temperature of $20-22^{\circ}$, are listed in table II (group 2). A moderate metabolic response to these conditions unaccompanied by activity and restlessness could be observed. The absence of changes in oxygen consumption caused by physical activity made it easier to assess SDA. The average changes in oxygen consumption are also shown in figure 4. Feeding was followed by a marked increase in oxygen consumption. The response was qualitatively and quantitatively similar to that observed at the neutral temperature. Only the duration of the effect differed somewhat in the two series of examinations, inasmuch as SDA reached the preingestion level only toward the end of the period of observation.

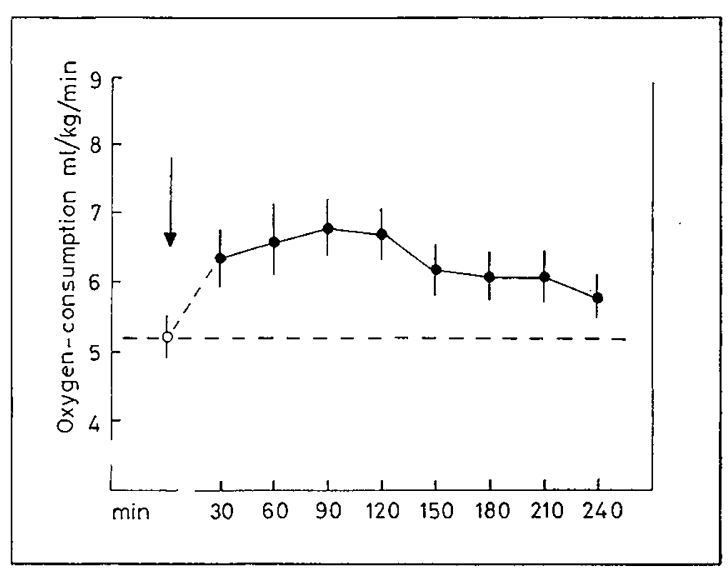

Fig.3. The oxygen consumption of premature infants before $(0)$ and at half-hour intervals after $(\bullet)$ the ingestion of an artificial formula in a thermoneutral environment (group 1). Vertical lines indicate the standard error of the means. 
Table II. The oxygen consumption of swaddled premature infants kept at $20-22^{\circ}$ after the ingestion of the artificial formula (group 2)

\begin{tabular}{|c|c|c|c|c|c|c|c|c|c|c|c|c|c|}
\hline \multirow[t]{2}{*}{$\begin{array}{l}\text { Age in } \\
\text { days }\end{array}$} & \multirow{2}{*}{$\begin{array}{c}\text { Body } \\
\text { weight } \\
\mathrm{g}\end{array}$} & \multirow{2}{*}{$\begin{array}{c}\mathrm{O}_{2} \text {-con- } \\
\text { sumption } \\
\text { at } \\
33-35^{\circ} \mathrm{G} \\
\mathrm{ml} / \mathrm{kg} / \\
\mathrm{min}\end{array}$} & \multirow{2}{*}{$\begin{array}{c}\mathrm{O}_{2} \text {-con- } \\
\text { sump- } \\
\text { tion at } \\
20^{\circ} \mathrm{C} \\
\mathrm{ml} / \mathrm{kg} / \\
\mathrm{min}\end{array}$} & \multirow{2}{*}{$\begin{array}{l}\text { Quantity } \\
\text { of food } \\
\mathrm{ml}\end{array}$} & \multicolumn{9}{|c|}{$\begin{array}{l}\mathrm{O}_{2} \text {-consumption } \mathrm{ml} / \mathrm{kg} / \mathrm{min} \text { at time (minutes) } \\
\text { after ingestion of food }\end{array}$} \\
\hline & & & & & 30 & 60 & 90 & 120 & 150 & 180 & 210 & 240 & 270 \\
\hline 7 & 1500 & 5.7 & 7.5 & 40 & 8.0 & 8.5 & 10.0 & 10.2 & 8.7 & 8.3 & 7.6 & 7.2 & 7.3 \\
\hline 12 & 1800 & 5.5 & 6.5 & 50 & 6.8 & 8.0 & 8.0 & 8.0 & 7.3 & 6.8 & 7.0 & - & - \\
\hline 16 & 1880 & 5.8 & 7.0 & 50 & 9.0 & 10.0 & 9.5 & 9.0 & 8.0 & 8.0 & 7.3 & - & - \\
\hline 28 & 2020 & 6.3 & 7.0 & 50 & 7.9 & 8.5 & 7.5 & 7.8 & 7.5 & 7.7 & 6.8 & 6.6 & - \\
\hline Means & & 5.8 & 7.0 & & 7.9 & 8.7 & 8.7 & 8.7 & 7.8 & 7.7 & 7.2 & 6.9 & - \\
\hline Standard & error \pm & 0.20 & 0.20 & & 0.45 & 0.43 & 0.60 & 0.47 & 0.32 & 0.32 & 0.17 & - & - \\
\hline
\end{tabular}

To see whether the metabolic increase caused by feeding was independent of the fasting level of thermoregulatory heat production below the critical temperature, examinations were carried out on partially swaddled infants who were divided into two groups according to the magnitude of the metabolic response to cold. Tables III and IV summarize the results obtained on those infants in whom levels of oxygen consumption rose by less than $2 \mathrm{ml} / \mathrm{kg} / \mathrm{min}$ (group 3, six infants, 6 to 27 days of age), or by more than $2 \mathrm{ml} / \mathrm{kg} /$ min, when exposed to room temperature (group 4, six

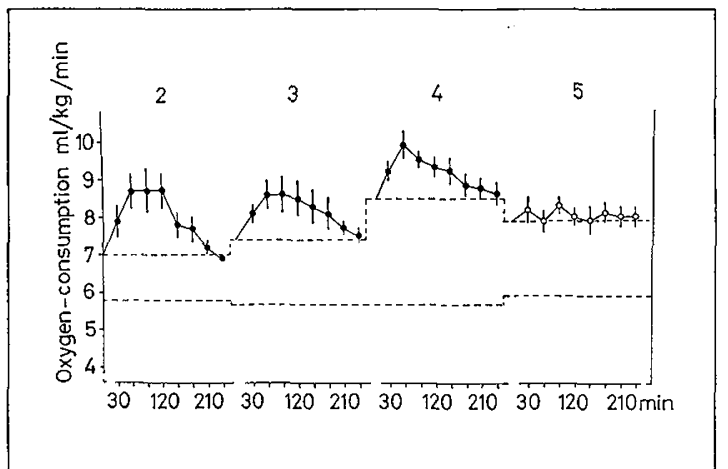

Fig.4. The means of oxygen consumption (•) and standard errors at half-hour intervals after the ingestion of the formula under heat-losing conditions (groups 2, 3,4). The oxygen consumption of fasting premature infants $(0)$ was also followed over an observation period of four hours (group 5). The lower interrupted line indicates the basal metabolic rate; the upper one shows the response to cold in the four series of examination. infants, 6 to 18 days of age), respectively. The average SDA observed at different levels of thermoregulatory heat production (groups 2, 3, and 4) is diagrammatically compared (fig. 4). It can be seen that the magnitude and the time course of the calorigenic effect of feeding do not differ appreciably despite the difference in the preingestion level of oxygen consumption.

A possible increase in activity may cause an increase in heat production. The degree of activity was not at a level that might have interfered with reliable assessment of SDA below the critical temperature. Complete or partial swaddling can result in reduced activity; hence a more uniform level of oxygen consumption can be obtained. This is shown by the control examinations (group 5) performed on four premature infants with two diapers wrapped around the legs and trunk (table $\mathrm{V}$ and fig.4). A comparison of the changes in oxygen consumption between fed and nonfed premature infants reveals that the increase in metabolic rate that occurs after feeding is not caused by muscular activity; it appears in an additive manner and independently of the metabolic increase induced by the cold environment.

To obtain the cumulative calorigenic effect, the total, basal, and thermoregulatory heat production for a period of four hours have been calculated. The participation of these factors in total energy expenditure is shown in table VI. The data show a decreasing tendency of the total extra amount of heat produced postprandially with the increasing metabolic response to cold, but even the value obtained at the highest preingestion level of the metabolic rate is not significantly different $(p>0.05)$ from that measured in the zone of thermoneutrality. 
Table III. The postprandial changes in oxygen consumption and colonic temperature of partially swaddled infants kept at 20-22 (group 3 )

\begin{tabular}{|c|c|c|c|c|c|c|c|c|c|c|c|c|c|c|c|c|c|c|c|c|c|c|}
\hline \multirow{3}{*}{ 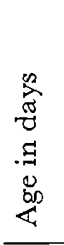 } & \multirow{3}{*}{ 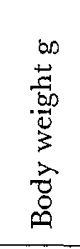 } & \multirow{3}{*}{ 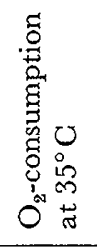 } & \multirow{3}{*}{ 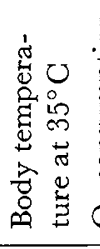 } & \multirow{3}{*}{ 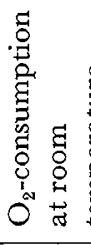 } & \multirow{3}{*}{ 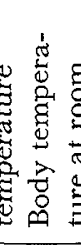 } & \multirow{3}{*}{ 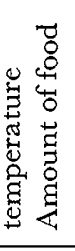 } & \multicolumn{16}{|c|}{$\mathrm{O}_{2}$-consumption $\mathrm{ml} / \mathrm{kg} / \mathrm{min}$ and body temperature during an experimental period of 4 hours } \\
\hline & & & & & & & \multicolumn{2}{|c|}{$30 \mathrm{~min}$} & \multicolumn{2}{|c|}{$60 \mathrm{~min}$} & \multicolumn{2}{|c|}{$90 \mathrm{~min}$} & \multicolumn{2}{|c|}{$120 \mathrm{~min}$} & \multicolumn{2}{|c|}{$150 \mathrm{~min}$} & \multicolumn{2}{|c|}{$180 \mathrm{~min}$} & \multicolumn{2}{|c|}{$210 \mathrm{~min}$} & \multicolumn{2}{|c|}{$240 \mathrm{~min}$} \\
\hline & & & & & & & $\mathrm{O}_{2}$ & $\mathrm{~T}$ & $\mathrm{O}_{2}$ & $\mathrm{~T}$ & $\mathrm{O}_{2}$ & $\mathrm{~T}$ & $\mathrm{O}_{2}$ & $\mathrm{~T}$ & $\mathrm{O}_{2}$ & $\mathrm{~T}$ & $\mathrm{O}_{2}$ & $\mathrm{~T}$ & $\mathrm{O}_{2}$ & $\mathrm{~T}$ & $\mathrm{O}_{2}$ & $\mathrm{~T}$ \\
\hline 6 & 1430 & 6.0 & 36.2 & 7.5 & 35.2 & 40 & 7.6 & 34.5 & 8.0 & 34.5 & 7.7 & 34.5 & 7.4 & 34.5 & 7.6 & 34.3 & 7.6 & 34.2 & 7.6 & 34.0 & 7.5 & 33.7 \\
\hline 6 & 1720 & 5.0 & 36.4 & 6.8 & 35.6 & 30 & 8.0 & 35.7 & 8.0 & 35.8 & 7.4 & 35.8 & 7.2 & 35.6 & 7.0 & 35.4 & 7.0 & 35.3 & 7.2 & 35.0 & 7.0 & 35.0 \\
\hline 8 & 1740 & 6.2 & 36.8 & 8.0 & 36.3 & 50 & 9.0 & 36.7 & 9.5 & 36.7 & 9.2 & 36.8 & 9.0 & 36.8 & 8.5 & 36.6 & 7.8 & 36.3 & 8.0 & 36.0 & 7.8 & 35.8 \\
\hline 12 & 1350 & 5.0 & 36.7 & 7.0 & 36.2 & 40 & 7.8 & 35.4 & 8.0 & 35.6 & 8.0 & 35.6 & 8.2 & 35.6 & 8.0 & 35.5 & 7.3 & 35.3 & 7.1 & 35.1 & - & - \\
\hline 19 & 1470 & 6.0 & 37.0 & 7.0 & 36.4 & 40 & 8.0 & 36.5 & 8.5 & 36.5 & 9.0 & 36.6 & 9.5 & 36.7 & 10.0 & 36.6 & 9.5 & 36.5 & 8.6 & 36.3 & - & - \\
\hline 27 & 1830 & 6.0 & 37.0 & 8.0 & 36.5 & 50 & 8.5 & 36.6 & 10.0 & 36.8 & 10.5 & 36.9 & 10.0 & 36.9 & 9.0 & 36.7 & 8.6 & 36.5 & 8.0 & 36.3 & 7.8 & 36.0 \\
\hline \multicolumn{2}{|c|}{ Means } & 5.7 & 36.7 & 7.4 & 36.0 & & 8.1 & 35.8 & 8.6 & 35.9 & 8.6 & 36.0 & 8.5 & 36.0 & 8.3 & 35.8 & 7.9 & 35.7 & 7.7 & 35.4 & 7.5 & 35.1 \\
\hline \multicolumn{2}{|c|}{$\mathrm{SE} \pm$} & 0.22 & 0.14 & 0.22 & 0.2 & & 0.21 & 0.35 & 0.35 & 0.33 & 0.47 & 0.35 & 0.46 & 0.34 & 0.43 & 0.36 & 0.42 & 0.34 & 0.23 & 0.34 & 0.19 & 0.50 \\
\hline
\end{tabular}

Table IV. The postprandial changes in oxygen consumption and colonic temperature of partially swaddled infants kept at $20-22^{\circ}$ and exhibiting a marked metabolic response to cold (group 4)

\begin{tabular}{|c|c|c|c|c|c|c|c|c|c|c|c|c|c|c|c|c|c|c|c|c|c|c|}
\hline \multirow{3}{*}{ 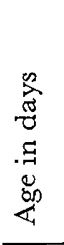 } & \multirow{3}{*}{ 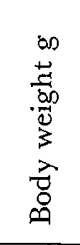 } & \multirow{3}{*}{ 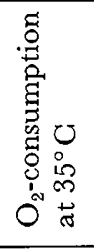 } & \multirow{3}{*}{ 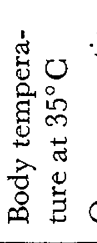 } & \multirow{3}{*}{ 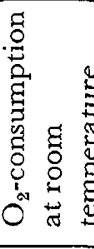 } & \multirow{3}{*}{ 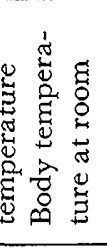 } & \multirow{3}{*}{ 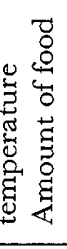 } & \multicolumn{16}{|c|}{$\mathrm{O}_{2}$-consumption $\mathrm{ml} / \mathrm{kg} / \mathrm{min}$ and body temperature during an experimental period of 4 hours } \\
\hline & & & & & & & \multicolumn{2}{|c|}{$30 \mathrm{~min}$} & \multicolumn{2}{|c|}{$60 \mathrm{~min}$} & \multicolumn{2}{|c|}{$90 \mathrm{~min}$} & \multicolumn{2}{|c|}{$120 \mathrm{~min}$} & \multicolumn{2}{|c|}{$150 \mathrm{~min}$} & \multicolumn{2}{|c|}{$180 \mathrm{~min}$} & \multicolumn{2}{|c|}{$210 \mathrm{~min}$} & \multicolumn{2}{|c|}{$240 \mathrm{~min}$} \\
\hline & & & & & & & $\mathrm{O}_{2}$ & $\mathrm{~T}$ & $\mathrm{O}_{2}$ & $\mathrm{~T}$ & $\mathrm{O}_{2}$ & $\mathrm{~T}$ & $\mathrm{O}_{2}$ & $\mathrm{~T}$ & $\mathrm{O}_{2}$ & $\mathrm{~T}$ & $\mathrm{O}_{2}$ & $\mathrm{~T}$ & $\mathrm{O}_{2}$ & $\mathrm{~T}$ & $\mathrm{O}_{2}$ & $\mathrm{~T}$ \\
\hline 6 & 1650 & 5.2 & 36.3 & 8.3 & 35.5 & 45 & 9.0 & 35.6 & 10.0 & 36.0 & 10.0 & 36.1 & 9.4 & 36.0 & 9.8 & 36.0 & 9.0 & 35.8 & 8.2 & 35.6 & 8.13 & 35.3 \\
\hline 7 & 1850 & 5.3 & 37.0 & 8.0 & 36.5 & 45 & 8.8 & 36.3 & 9.0 & 36.6 & 8.8 & 36.8 & 8.5 & 36.7 & 8.2 & 36.4 & 7.8 & 36.2 & 7.8 & 36.0 & 8.03 & 35.8 \\
\hline 8 & 1660 & 5.5 & 36.7 & 8.0 & 36.3 & 45 & 8.6 & 36.7 & 9.2 & 36.4 & 9.3 & 36.5 & 9.0 & 36.6 & 8.7 & 36.3 & 8.5 & 36.1 & 8.5 & 35.8 & 8.23 & 35.5 \\
\hline 15 & 1540 & 6.2 & 37.1 & 9.0 & 36.6 & 50 & 9.8 & 36.3 & 11.0 & 36.7 & 10.0 & 36.5 & 10.0 & 36.8 & 10.0 & 36.7 & 10.0 & 36.4 & 9.7 & 36.2 & 9.43 & 36.0 \\
\hline 17 & 1580 & 6.0 & 37.1 & 9.2 & 36.6 & 50 & 10.0 & 36.4 & 9.4 & 36.6 & 9.2 & 36.9 & 9.3 & 36.4 & - & - & 8.8 & 36.2 & 9.0 & 35.8 & 9.23 & 35.6 \\
\hline 18 & 1680 & 6.0 & 36.8 & 8.8 & 36.0 & 45 & 9.0 & 36.0 & 10.8 & 36.4 & 9.5 & 36.6 & 9.8 & 36.5 & 9.2 & 36.5 & 9.0 & 36.3 & 9.2 & 36.0 & 9.03 & 35.9 \\
\hline \multicolumn{2}{|c|}{ Mean } & 5.7 & 36.8 & 8.5 & 36.2 & & 9.2 & 36.3 & 9.9 & 36.4 & 9.5 & 36.5 & 9.3 & 36.5 & 9.2 & 36.4 & 8.8 & 36.1 & 8.7 & 35.9 & 8.63 & 35.7 \\
\hline \multicolumn{2}{|c|}{$\overline{\mathrm{SE}} \pm$} & 0.17 & 0.13 & 0.21 & 0.18 & - & 0.23 & 0.16 & 0.35 & 0.10 & 0.17 & 0.10 & 0.22 & 0.11 & 0.32 & 0.11 & 0.28 & 0.10 & 0.29 & 0.09 & 0.25 & 0.11 \\
\hline
\end{tabular}


Since SDA does not replace thermoregulatory heat production, but appears as an additional amount of heat, an assumption can be made that it contributes to the maintenance of body temperature. The changes in body temperature observed in partially swaddled, fed infants (groups 3, 4, and 5) and in unfed control infants maintained under the same conditions emphasize the importance and usefulness of the thermic response to food in a heat-losing environment. Feeding not only stopped or decreased the rate of fall in body temperature, but also caused a transient rise in relation to the preingestion level (tables III, IV, and V). This favorable thermic effect can be explained by the postprandial rise in heat production.

\section{Discussion}

Howland [9] and Benedict and Talbot [1] were among the first to show that ingestion of food increases heat production in infants from 3 to 13 months of age in the same manner as it does in adults. In these first investigations on human infants, it was also shown that among the nutrients, protein exerted the greatest calorigenic effect, which amounted to $10.42 \%$ of the control metabolism. Benedict and TALBOT [1] observed that a feeding that contains $50 \mathrm{kcal}$ may augment metabolism for four hours; this finding corresponds well with the time course of SDA observed in the present investigation.

MurLin et al. [18], the first to demonstrate the calorigenic effect of human milk on newborn infants, found a metabolic increase of $6.8 \%$. Later, LEVINE $e t$ al. [12] and Shadow [12, 23] reported observations that might have some relevance to the present findings. They demonstrated that in infants, feedings of dilution of cow's milk containing $122 \mathrm{kcal}$ cause an increase in heat production of 6-9\% above the preingestion level. The greatest stimulation of metabolism (about $18 \%$ ) occurred after an increase of protein intake in the form of casein.

DANN $e t$ al. [6] tested the metabolic effect of various amino acids in full-term and in premature infants and found an increase in heat production from 6 to $15 \%$ above the control value after the ingestion of glycine in a dose of $1 \mathrm{~g} / \mathrm{kg}$ of body weight. A similar effect was observed in full-term infants by Esposti [7]. Recently, Kövér and Kiss-Szabo [11] studied 16 lightly dressed premature infants who were kept at an ambient temperature of $30^{\circ}$ and given glycine by gavage in an amount of $2 \mathrm{~g} / \mathrm{kg}$. The average increase in basal metabolic rate amounted to $19 \%$. The greatest calorigenic effect in premature infants (32\% of the control metabolic rate) was obtained with a casein hydrolysate [8] fed to infants maintained at a room temperature of $22-24^{\circ}$. 
Table VI. The partitioning of the total energy metabolism of premature infants maintained at and below the neutral temperature into its components. The extra amount of heat produced postprandially at different levels of chemical heat regulation is expressed in terms of caloric intake

\begin{tabular}{|c|c|c|c|c|c|c|c|}
\hline \multirow[t]{3}{*}{ Food } & \multirow{3}{*}{$\begin{array}{c}\text { Environmental } \\
\text { temperature } \\
{ }^{\circ} \mathrm{G}\end{array}$} & \multicolumn{3}{|c|}{$\begin{array}{l}\text { Energy metabolism during } \\
\text { a period of } 240 \text { minutes }\end{array}$} & \multirow{2}{*}{$\begin{array}{c}\text { Extra } \\
\text { calories } \\
\text { produced } \\
\text { after } \\
\text { the feed }\end{array}$} & \multirow[t]{3}{*}{$\begin{array}{l}\text { Caloric } \\
\text { intake }\end{array}$} & \multirow{3}{*}{$\begin{array}{c}\text { Specific } \\
\text { dynamic } \\
\text { action in } \\
\text { terms of } \\
\text { caloric } \\
\text { intake } \\
\%\end{array}$} \\
\hline & & $\begin{array}{c}\text { Basal } \\
\text { metabolism }\end{array}$ & $\begin{array}{l}\text { Metabolic } \\
\text { response } \\
\text { to cold }\end{array}$ & $\begin{array}{c}\text { Total } \\
\text { metabolism }\end{array}$ & & & \\
\hline & & \multicolumn{4}{|c|}{$\mathrm{kcal} / \mathrm{kg}$} & & \\
\hline Adapta & $33-35$ & $\begin{array}{r}6.00 \\
\pm 0.28\end{array}$ & - & $\begin{array}{r}7.70 \\
\pm 0.40\end{array}$ & $\begin{array}{r}1.70 \\
\pm 0.28\end{array}$ & 18.8 & 9.2 \\
\hline Adapta & $\begin{array}{c}20-22 \\
\text { swaddled }\end{array}$ & $\begin{array}{r}6.70 \\
\pm 0.07\end{array}$ & $\begin{array}{r}7.86 \\
+0.07\end{array}$ & $\begin{array}{r}9.40 \\
\pm 0.46\end{array}$ & $\begin{array}{r}1.54 \\
\pm 0.34\end{array}$ & 18.5 & 8.3 \\
\hline Adapta & $\begin{array}{c}20-22 \\
\text { partially swaddled }\end{array}$ & $\begin{array}{r}6.60 \\
\pm 0.27\end{array}$ & $\begin{array}{r}8.53 \\
\pm 0.24\end{array}$ & $\begin{array}{r}9.90 \\
\pm 0.43\end{array}$ & $\begin{array}{r}1.37 \\
\pm 0.33\end{array}$ & 18.1 & 7.7 \\
\hline Adapta & $\begin{array}{c}20-22 \\
\text { partially swaddled }\end{array}$ & $\begin{array}{r}6.60 \\
\pm 0.21 \\
\end{array}$ & $\begin{array}{r}9.82 \\
\pm 0.26\end{array}$ & $\begin{array}{r}11.03 \\
\pm 0.32\end{array}$ & $\begin{array}{r}1.20 \\
\pm 0.22\end{array}$ & 19.0 & 6.3 \\
\hline Controls & $20-22$ & $\begin{array}{r}6.80 \\
\pm 0.20\end{array}$ & $\begin{array}{r}9.12 \\
\pm 0.37\end{array}$ & $\begin{array}{r}9.40 \\
\pm 0.32\end{array}$ & $\begin{array}{r}0.28 \\
\pm 0.01\end{array}$ & - & - \\
\hline
\end{tabular}

The present results confirm the observation that in the majority of premature infants, an artificial formula $(40-60 \mathrm{ml})$ may induce an increase in heat production. The rate of oxygen consumption increases over a period of two hours and then falls rapidly, approaching the fasting level four hours postprandially. The failure of some infants to show an increase in oxygen consumption is difficult to explain. It may be due to a marked delay and a very slow rate in absorption of nutrients, or perhaps the preliminary levels in oxygen consumption were not basal in these infants.

The increase in heat production following food intake results in a greater expenditure of energy and is an additional factor to be considered in the energy metabolism of maintenance. The method of expressing the magnitude of SDA should be clearly defined. The generally accepted mode of expression is based on a method that relates the increase in heat production to the fasting metabolic rate. To properly visualize the cost of the calorigenic effect of food, it would be useful to relate SDA to total caloric intake. Using this method, it has been found that following ingestion of formula, the total heat increment for the 4-hour period of observation averaged $1.70 \mathrm{kcal} / \mathrm{kg}$, representing a $9.2 \%$ of the calories consumed. Thus, a daily caloric intake of $130 \mathrm{kcal} / \mathrm{kg}$ caused a rise in heat production of $11.96 \mathrm{kcal} / \mathrm{kg} / 24 \mathrm{~h}$, which, in the zone of thermoneutrality, may reasonably be regarded as a waste of energy. This amount of heat could be considered to be a small increase in energy expenditure; however, assuming a fasting metabolic rate of $45 \mathrm{kcal} / \mathrm{kg} / 24 \mathrm{~h}$, the same daily heat increment amounts to $26.6 \%$ in terms of the minimal metabolism and cannot be regarded as negligible in the energy metabolism of premature infants. It should also be kept in mind that an even greater proportion of basal metabolism can be dissipated as SDA if the daily intake of calories exceeds $150 \mathrm{kcal} / \mathrm{kg}$. In this case, the extra calories produced might be a significant thermal load to the premature infant cared for in a thermoneutral environment. Considering the various factors upon which the zone of thermoneutrality depends, it is not surprising that an increase of $30 \%$ of the basal heat production of premature infants fed a protein-rich diet can be of thermoregulatory significance.

Ever since RUBNER [21] observed that below the critical temperature of the fasting animal the thermogenic effect of food decreases in proportion to the fall in ambient temperature, it has been a common teaching that SDA may partially or completely replace the metabolic response to cold. In other words, while within the thermoneutral zone the metabolic effect of food is independent of changes in ambient temperature; in a cold environment, it does not manifest itself as an additional amount of heat, but replaces thermoregulatory heat production induced and controlled by chemical thermoregulation. In testing the validity of RUBNER's concept in adults, BUSkIRK et al. [5] came to the conclusion that below the critical temperature, cold and eating exert independent effects upon heat 
production. The results of our investigation fully support the observation of Buskirk et al., since the magnitude of the total calorigenic effect is not significantly different from that obtained in a thermoneutral environment.

The independence of the stimulating effect of food and cold on thermogenesis is obvious in three of the test series (groups 2, 3, and 4), which represent an average metabolic increase of 21,30 and $49 \%$ as a result of exposure to cold. It would be interesting to know whether in infants exhibiting a metabolic response to cold exceeding 50 percent of the basal level, SDA would also appear in an additive manner. Unfortunately, a more pronounced increase in thermoregulatory heat production usually seen in infants exposed nakedly to a heat-losing environment is always associated with vigorous activity and restless crying, which makes it impossible to distinguish between the increase in metabolism caused by muscular activity and that caused by the stimulus of food. Complete or partial swaddling practically eliminates intensive muscular activity; under such conditions, one can be reasonably certain that the observed increase above the preingestion level of oxygen consumption represents SDA. It is conceivable, however, that even intensive activity would not interfere with the measurement of SDA. RAPPORT [20] and KAPLAN [10] reported that the calorigenic effect of protein was superimposed on the elevated metabolism associated with muscular exercise. The observations of STOCK [25] suggest a greater calorigenic response to a meal in the active state, when compared with the resting state.

The summation of the metabolic response to cold and to food is also reflected by the behavior of body temperature. The ingestion of a formula in an amount of $50 \mathrm{ml}$ stopped the fall in body temperature and even caused a small transient rise during the period of maximum heat production. This favorable effect on core temperature indicates an increased tolerance to cold of premature infants fed a formula containing $3.4 \%$ protein, and suggests that SDA serves to help maintain body temperature in a cold environment. Further observations are, of course, needed to clarify the thermoregulatory significance of postprandial thermogenesis in premature infants maintained on different feeding regimens and cared for under various thermal conditions.

\section{Summary}

Oxygen consumption of premature infants was continuously recorded after the ingestion of formula containing $3.43 \%$ protein at and below the neutral temperature.
In the zone of thermoneutrality, the total extra calories produced after ingestion of the formula averaged $1.7 \mathrm{kcal} / \mathrm{kg}$ which, in terms of basal metabolic rate and ingested calories, represented an increase of 28.4 and $9.2 \%$, respectively. This amount of heat cannot be regarded as a negligible component of energy metabolism and may represent a significant thermal load to the premature infant cared for in a thermoneutral environment.

Specific dynamic action is more or less independent of the fasting level of thermoregulatory heat production below the critical temperature; the total extra amount of heat produced postprandially is not significantly less than that obtained in the zone of thermoneutrality.

The calorigenic effect of food superimposed on the metabolic response to cold is also reflected by the decreased rate of fall in body temperature and demonstrates the usefulness of postprandial thermogenesis in temperature regulation of premature infants.

\section{References and Notes}

1. Benedict, F.G. and Talbot, F.B.: Metabolism and growth from birth to puberty. Publication No.302, p.95 (Carnegie Institute, Washington 1921).

2. BRüGK, K.; BRüCK, M. und Lemtis, H.: Thermoregulatorische Veränderungen des Energiewechsels bei reifen Neugeborenen. Pflüger's Arch.ges. Physiol. 267: 382 (1958).

3. BRüGk, K.: Temperature regulation in the newborn infant. Biol. Neonat. 3: 65 (1961).

4. Brück, K.; Parmalee, A.H. Jr. and Brück, M. : Neutral temperature range and range of 'thermal comfort' in premature infants. Biol. Neonat. 4: 32 (1962).

5. Buskirk, E.R.; Thompson, R.M. and Whedon, G.D.: Human energy expenditure studies in the National Institute of arthritis and metabolic diseases. I. Interaction of cold environment and specific dynamic effect. Amer.J.clin. Nutrit. 8: 602 (1960).

6. Dann, M.; Kelly, M.D.; MaNamara, H. and Gurris, J. C. : The specific dynamic action of amino acids in infants. Amer. J. Dis. Child. 63: 900 (1942).

7. Esposxr, D.A.: L'azione dinamico specifica di alcuni aminoacidi introdotti per via orale studiata nell'infanzia. Clin.pediat. (Bologna) 31: 291 (1949).

8. Gamalero, P. G. e Crosato, M.: Ricerche sulla azione dinamico-specifica degli idrolisati proteici e delle proteine nell'immaturo. Minerva pediat. (Torino) 10: 1217 (1958). 
9. Howland, J.: Der Chemismus und Energieumsatz bei schlafenden Kindern. Hoppe-Seylers Z.Physiol. Chem. 74: 1 (1911).

10. Kaplan, P.M.: Die spezifisch-dynamische Wirkung der gemischten Kost. Arbeitsphysiologie 6: 411 (1933).

11. Kövér, B. und Krss-Szabó, A. : Beiträge zur Frage der spezifisch-dynamischen Wirkung auf Grund von Glykokoll-Belastungen bei Frühgeborenen. Acta paediat. Acad. Sci.hung. 4: 33 (1963).

12. Levine, S.E.; Wilson, J.R.; Berliner, F. and RrvkIN, H.: VI. The specific dynamic action of food in normal infants. Amer. J. Dis. Child. 33: 722 (1927).

13. Mestyán, J.; Fekete, M.; Bata, G. and JÁrai, I. : A környezeti hömérséklet és koraszülöttek fenntartási kaloriaszükséglete az extrauterin élet elsö honapjában. Gyermekgyögyäszat XVI: 44 (1965).

14. Mestyán, J. and Varga, F.: Chemical thermoregulation of full term and premature newborn infants. J.Pediat. 56: 623 (1960).

15. Mestyán, J.; Járai, I.; Fenete, M. and Soltész, Gy.: Unpublished data.

16. Mestyán, J.; Járar, I. and Fenete, M.: The total energy expenditure and its components in premature infants maintained under different nursing and environmental conditions. Pediat. Res. 2: 161 (1968).

17. Mrahaelis, A. M.: Clinical colorimetry. A graphic method of determining certain numerical factors in metabolism. J.biol. Chem. 95: 51 (1924).
18. Murlin, J.H.; Conklin, R. E. and Marsh, M.E.: Energy metabolism of normal newborn babies with special reference to the influence of food and crying. Amer.J. Dis. Child. 29: I (1925).

19. PŘibylová, H. und Znamenáček, K.: Über die Entwicklung von einigen Indices der chemischen und physikalischen Thermoregulation bei unreifen Kindern. Ann. paediat. (Basel) 201: 305 (1963).

20. RAPPORT, D. : The nature of the foodstuffs oxidized to provide energy in muscular exercise. III. The utilisation of the 'waste heat' of metabolism in muscular exercise. Amer.J. Physiol. 91: 238 (1929).

21. Rubner, M.: Die Gesetze des Energieverbrauches bei der Ernährung (Deuticke, Leipzig/Wien 1902).

22. Schadow, H.: Grundumsatz und spezifisch-dynamische Wirkung bei gesunden Säuglingen im Vergleich mit den Befunden bei Erwachsenen und älteren Kindern. Jb. Kinderheilk. 125: 50 (1930).

23. Schadow, H.: Der Betriebsstoffwechsel und Kalorienbedarf frühgeborener Säuglinge. Jb. Kinderheilk. 136: 1 (1932).

24. Scopes, J.W. and Ahmed, I.: Range of critical temperature in sick and premature newborn babies. Arch. Dis. Childh. $41: 417$ (1966).

25. Sтоck, M.J.: The thermic response to meals of varying size in the resting and active human subject. Proc. Nutr. Soc. 38: 25 (1966).

26. Egyesült Gyógyszer-és Tápszergyár, Budapest.

27. Requests for reprints should be addressed to J. Mestyán, M.D., Department of Pediatrics, University of Pécs, Pécs (Hungary). 